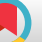

\title{
Investigating Antibacterial Properties of Tecomella undulata and Momordica charantia Plant Extracts on Some Pathogenic Bacteria
}

\author{
Hojjat Khosravi ${ }^{1}$, Mahmoud Solouki ${ }^{1,{ }^{*}}$ and Salehe Ganjali ${ }^{1}$ \\ ${ }^{1}$ Department of Plant Breeding and Biotechnology, Faculty of Agriculture, Zabol University, Zabol, Iran \\ "Corresponding author: Associate Professor, Department of Plant Breeding and Biotechnology, Faculty of Agriculture, Zabol University, Zabol, Iran. Email: \\ mahmood.solouki@uoz.ac
}

Received 2019 June 05; Revised 2019 October 13; Accepted 2019 October 20.

\begin{abstract}
Background: Today, due to microbial resistance to antibiotics, herbs and their compounds are commonly used as alternative antibiotics. The extracts of some plants can inhibit the growth of microorganisms as new antimicrobial agents. Thus, they can have great applications in medical science and food industry.

Objectives: The aim of this study was to investigate the antibacterial effects of Tecomella undulata and Momordica charantia extracts on Escherichia coli, Staphylococcus aureus, Pseudomonas aeruginosa, and Shigella dysenteriae.

Methods: After the identification and collection of plant samples, they were dried and underwent extraction using a rotary machine following the soaking method. The microdilution method was used to determine the antibacterial properties of the extracts on standard strains of Escherichia coli, Staphylococcus aureus, Pseudomonas aeruginosa, and Shigella dysenteriae.

Results: The minimum inhibitory concentrations of Tecomella undulata extract against the studied bacteria were 1.87 to $3.75 \mathrm{mg} / \mathrm{ml}$. The highest lethal concentration of leaf extract was $15 \mathrm{mg} / \mathrm{mL}$ and the lowest lethal concentration of Momordica charantia extract was 1.87 to $3.75 \mathrm{mg} / \mathrm{mL}$. The highest Momordica charantia extract concentration was $15 \mathrm{mg} / \mathrm{mL}$ and Shigella dysenteriae were eliminated at this concentration,

Conclusions: The results of this study revealed that various concentrations of the hydroalcoholic extract of Tecomella undulata and Momordica charantia had inhibitory effects on human pathogens.
\end{abstract}

Keywords: Hydroalcoholic Extract, Antibacterial Effect, Tecomella undulata, Momordica charantia, Drug Resistance

\section{Background}

Bacterial diseases are among the most well-known diseases that have always affected humans and much effort has been made to identify, control, and treat these diseases (1). The plants synthesize materials to combat and protect themselves against insects and microorganisms. Moreover, they can produce antimicrobial metabolites to affect the natural growth of microorganisms. Despite numerous medical discoveries in various fields of drug and advanced therapy, the rates of infectious diseases in developing countries are rising (2). At the same time, a large portion of outbreaks and human mortalities is attributed to bacterial diseases that can enter the human body in various ways, such as drinking water, breathing, and eating food (3).

Escherichia coli as a Gram-negative bacterium belonging to the Enterobacteriaceae family is one of the most important agents causing urinary tract infections and bacteremia. Escherichia is also one of the most common bac- teria causing hospital infections (4). Staphylococcus aureus, with a relatively high prevalence, is among the main causes of nosocomial infections and contributes to the development of a wide range of diseases. It is estimated that $25 \%$ - 30\% of people in different populations carry S. aureus in their nose, which in most cases is the source of the infection of natural carriers (5). As an opportunistic and important hospital pathogen, Pseudomonas aeruginosa has great resistance to antibiotics $(6,7)$ so that the treatment of infections caused by this bacterium has always been a challenge $(8,9)$. Moreover, $P$. aeruginosa is one of the main causes of mortality in immunocompromised patients and individuals with severe burns and cystic fibrosis $(10,11)$; thus, it is considered a very serious threat to hospitalized patients worldwide (12). Shigella dysenteriae is also one of the key bacterial causes of bloody diarrhea, affecting about 450000 people each year in the United States can cause complications, including bacteremia and even death, especially in children, adults, and immunocompromised pa- 
tients (13).

There is a constantly increasing tendency of producing medicinal plants and increasing demand for these natural products in the world. Following the identification of possible negative effects of chemical compounds since the mid-twentieth century, these compounds have been replaced significantly by herbal drugs in many cases (14). Tecomella undulata, with the scientific name of Reodana and Rohida, is called Samang and Parpovak in Fars and Sistan and Baluchistan provinces, respectively (15). As a shrub, it is an evergreen tree of the Bignoniaceae family (16). The plant organs are used to treat syphilis and eczema. Its skin has sedative, cardiotonic, and antispasmodic activity. The plant's is used to treat spleen, gonorrhea, and hepatomegaly. Bitter cucumber with the scientific name of Momordica charantia and the English name of Bitter melon is native to Asia, and was used in ancient medicine for the treatment of infectious diseases and pain relief (17).

\section{Objectives}

One of the most suitable methods for investigating the effects of herbal extracts on bacteria is to determine the minimum inhibitory concentration (MIC) or minimum bactericidal concentration (MBC). The aim of this study was to determine the minimum concentration of plant extracts for the growth inhibition of different bacterial strains using the MIC and MBC methods.

\section{Methods}

All bacterial strains were collected from Iran's fungal and bacterial colonies (Enghelab Research Center Complex, Hassan Abad, Khaleseh Road, Badamak Bridge underpass, Shahriar Road, Old Road of Karaj, Iran, E-mail: ptcc@irost.org)

\subsection{Collection of Plants and Preparation of Extracts}

The leaves of Tecomella undulata and fruits of Momordica charantia were harvested, dried, and ground after being identified in all over the cities of Jiroft and Chabahar (Table 1). For ease of extraction, flocculants were powdered by an electric mill.The extraction was done by the maceration or soaking method. To prepare the extracts, $100 \mathrm{~mL}$ of ethanol $98 \%$ and distilled water was added to $10 \mathrm{~g}$ of dried powder in a sterile container and kept on a shaker in room for 24 hours. Then, the extracts were filtered using filter papers and the extra solvent was removed using a rotary machine. The residual solution containing the extracts is poured into a sterile glass container and placed in an oven at $45^{\circ} \mathrm{C}$ to dry completely. The dried extracts were collected

\begin{tabular}{lcc}
\hline Table 1. Features of Plants Used in This Study & \\
\hline English Name & Family Name & Latin Name \\
\hline Desert Teak & Bignoniaceae & Tecomella undulata \\
Bitter melon & Cucurbitaceae & Momordica charantia \\
\hline
\end{tabular}

and kept in a refrigerator away from the light until tests were performed (18).

\subsection{Microbial Suspension of 0.5 McFarland Turbidity}

To prepare microbial suspensions, a day before the experiment, a small portion of bacterial colonies was transferred to the agar (German mercury) culture medium. After the growth of bacterial cells on the medium surface, the surface was washed with the normal saline solution and the concentrated microbial suspension was calibrated. Then, some bacterial suspensions were poured into a tube containing normal saline and its optical density was measured with a spectrophotometer at $530 \mathrm{~nm}$ wavelength. Then, Its turbidity was measured by spectrophotometer at $530 \mathrm{~nm}$. The final concentration of the suspension was determined to be $1.5 \times 10^{8} \mathrm{CFU}(19)$.

\subsection{Antimicrobial Tests of Extracts}

For this test, Escherichia coli, Staphylococcus aureus, Pseudomonas aeruginosa, and Shigella dysenteriae strains were used. Using the microbroth dilution method, in each well of a microplate was added $100 \mu \mathrm{L}$ of nutrient broth medium (Merck, Germany). Then, $100 \mu \mathrm{L}$ of diluted extracts were added to the first well and after mixing, 100 $\mu \mathrm{L}$ was removed from the first well and added to the second one. This procedure was repeated to the last well and finally, the last wells were added with $100 \mu \mathrm{L}$ of extraction medium and $10 \mu \mathrm{L}$ of the microbial suspension containing $10^{8}$ units per ml equal to 0.5 McFarland. Also, two wells were considered as controls, one containing only the extract and the other having only bacterial suspensions. After being incubated for 24 hours at $37^{\circ} \mathrm{C}$, the first nonturbid well was considered as the MIC, which indicated the minimum inhibitory concentration of the extract for growth inhibition (20).

\section{Results}

The results of this study showed that the MICs of Tecomella undulata leaf extract against Escherichia coli, Staphylococcus aureus, Pseudomonas aeruginosa, and Shigella dysenteriae were $7.5,1.87,7.5$, and $3.75 \mathrm{mg} / \mathrm{mL}$, respectively, indicating the highest effect against Staphylococcus aureus with a minimum concentration of 1.87 $\mathrm{mg} / \mathrm{mL}$ (Table 2). The highest lethal concentration of 
the extract of Tecomella undulata was $15 \mathrm{mg} / \mathrm{mL}$ against Escherichia coli and Pseudomonas aeruginosa (Table 2).

The results of this study showed that showed that the MICs of Momordica charantia fruit extract against Escherichia coli, Pseudomonas aeruginosa, Staphylococcus aureus, and Shigella dysenteriae were $3.75,3.75,1.87$, and 7.5 $\mathrm{mg} / \mathrm{mL}$, which showed the highest effect on Staphylococcus aureus with a minimum concentration of $1.87 \mathrm{mg} / \mathrm{mL}$ (Table 3). The highest lethal concentration was $15 \mathrm{mg} / \mathrm{mL}$ against Shigella dysenteriae (Table 3 ).

Table 2. Results of Tecomella undulata Hydroalcoholic Leaf Extract Test on Pathogenic Bacteria

\begin{tabular}{lcc}
\hline Standard Bacteria & $\begin{array}{c}\text { Minimum Bactericidal } \\
\text { Concentration(MBC) } \\
(\mathbf{m g} / \mathbf{m L})\end{array}$ & $\begin{array}{c}\text { Minimum Inhibitory } \\
\text { Concentration(MIC) } \\
(\mathbf{m g} / \mathbf{m L})\end{array}$ \\
\hline E. coli & 15 & 7.5 \\
S. aureus & 3.75 & 1.87 \\
P. aeruginosa & 15 & 7.5 \\
S. dysenteriae & 7.5 & 3.75 \\
\hline
\end{tabular}

Table 3. Results of Momordica charantia Hydroalcoholic Fruit Extract Test on Pathogenic Bacteria

\begin{tabular}{lcc}
\hline Standard Bacteria & $\begin{array}{c}\text { Minimum Bactericidal } \\
\text { Concentration }(\mathbf{M B C}) \\
(\mathbf{m g} / \mathbf{m L})\end{array}$ & $\begin{array}{c}\text { Minimum Inhibitory } \\
\text { Concentration (MIC) } \\
(\mathbf{m g} / \mathbf{m L})\end{array}$ \\
\hline E. coli & 7.5 & 3.75 \\
S. aureus & 3.75 & 1.87 \\
P. aeruginosa & 7.5 & 3.75 \\
S. dysenteriae & 15 & 7.5 \\
\hline
\end{tabular}

\section{Discussion}

One of the current problems with the treatment of bacterial infections is their increased resistance to antibiotics. Antibiotic-resistant bacteria can cause significantly more deaths than non-resistant bacteria $(21,22)$. With increasing the resistance of antibiotics, efforts are being made around the world to use new therapies (22). As important sources of new chemotherapy drugs, medicinal herbs are of particular interest due to their wide range of bioactive constituents. Herbal medicines are more compatible with living organisms, including the human body because of their natural origin compared to chemical drugs; they produce fewer side effects $(23,24)$.

The results of this study showed that hydroalcoholic extracts of Tecomella undulata and Momordica charantia plants at different concentrations could inhibit Grampositive and negative bacteria. In a study by Abhishek et al., the MICs of the methanolic extract of Tecomella undulata against B. subtilis, E. faecalis, E.coli, K. pneumonia, M. luteus, P. vulgaris, and P. aeruginosa were 4, 2, 0.1,1-0, 2 - 0, and $2 \mathrm{mg} / \mathrm{mL}$, respectively (25).

In a study carried out by Bhardwaj to investigate the antimicrobial and antifungal activities of the alkaloids of Tecomella undulata extract, the results showed that the inhibition zone diameters against fungi F. oxysporum, $P$. funiculosum, C. albicans, and T. viride were $18.66 \pm 1.52,18.66$ $\pm 0.57,27.66 \pm 1.52$, and $26.66 \pm 1.05$, respectively, and the inhibition zone diameters of $S$. aureus, E.coli, E. faecalis, $B$. subtilis, and K. pneumonia were $17 \pm 1,20 \pm 1,11.66 \pm 2.8$, $21.66 \pm 2.51$, and $0 \mathrm{~mm}$, respectively (26).

In Thanawala et al. study, the inhibition zone diameters of Estonian Tecomella undulata extract against B. subtilis, E. coli, P. aeruginosa, and S. aureus were 17, 0, 0, and 10 $\mathrm{mm}$ and the inhibition zone diameters of the alcoholic extract against these bacteria were $0,9,0,0 \mathrm{~mm}$, respectively (27).

In a study conducted by Akinsiku et al. using synthetic nanoparticles from Momordica charantia stems on some bacteria, the synthesized nanoparticles showed antibacterial and inhibitory effects. The results also showed that the lowest inhibitory concentration and the least destructive concentration were $12.5 \mathrm{mg} / \mathrm{mL}$ and the lowest activity of these particles was detected against $P$. aeruginosa with MIC of $50 \mathrm{mg} / \mathrm{mL}$ and $\mathrm{MBC}$ of $100 \mathrm{mg} / \mathrm{mL}$ (28).

In a study by Nguyen et al., the antimicrobial activities of four types of extracts including hexane, chloroform, ethyl acetate, and methanol-water were studied against four bacterial species and four fungal species. The results revealed that chloroform extract was more effective than the other extracted oil essences so that the MIC against $E$. coli and B. subtilis was $200 \mathrm{mg} / \mathrm{mL}$ and in the case of A. niger, it was $100 \mathrm{mg} / \mathrm{mL}$. Also, A. niger had a relatively high sensitivity to all extracts, except for methanol-water extract (29).

Subramania et al. investigated the antimicrobial activity of $\beta$-sitosterol-D-glucopyranoside isolated from the hydroalcoholic extract of Desmostachya bipinnata. They showed a MIC of $6-50 \mu \mathrm{g} / \mathrm{mL}$ and the time to kill curves showed that $\beta$-sitosterol-D-glucopyranoside eliminated many pathogens in $5-10$ hours (30).

Abhishek et al. investigated the antibacterial effect of the leaves of Tecomella undulata on human pathogens. Hexane, chloroform, and methanol extracts were used for testing using seven agar-well diffusion methods. The methanol extract showed higher antibacterial activity than the other two solvents. They also reported that methanol extract showed a higher inhibitory concentration against Klebsiella pneumoniae and Micrococcus Lotus. The study also found that Gram-negative bacteria were more sensitive than Gram-positive bacteria (25). 


\subsection{Conclusions}

According to the results of this study, hydroalcoholic extracts of Tecomella undulata and Momordica charantia had significant antimicrobial effects on Escherichia coli, Staphylococcus aureus, Pseudomonas aeruginosa, and Shigella dysenteriae. Finally, it can be concluded that the extracts of these plants can be used for their antimicrobial effects in the pharmaceutical and food industries and they can be an important and natural source of compounds for controlling and treating diseases caused by these bacteria. However, the clinical use of the extracts of these plants requires further study.

\section{Footnotes}

Authors' Contribution: Laboratory studies and tests: Hojjat Khosravi; study and review: Mahmoud Solouki; analysis and interpretation of data: Salahe Ganjali.

Conflict of Interests: The authors declare no conflict of interest.

\section{Ethical Approval: The code of ethics was IRUOZ.ECRA161296.}

Funding/Support: This study was supported by the University of Zabol, Zabol, Iran.

Informed Consent: Written informed consent was obtained.

\section{References}

1. Feyzi M, editor. [Introduction of the Satureja bachtiarica and its ecological characteristic in Esfahan provice]. Proceeding of National Iranian Congress of Medical Plants. 2002; Tehran, Iran. 2002. Persian.

2. Marzouk Z, Neffati A, Marzouk B, Chraief I, Fathia K, Ghedira LC, et al Chemical composition and antibacterial and antimutagenic activity of Tunisian Rosmarinus officinalis L. oil from Kasrine. J Food Agr Environ. 2006;4(3/4):61.

3. Abdel-Massih R, Abdou E, Baydoun E, Daoud Z. Antibacterial activity of the extracts obtained from Rosmarinus officinalis, Origanum majorana, and Trigonella foenum-graecum on highly drug-resistant gram negative bacilli. J Bot. 2010;2010:1-8. doi: 10.1155/2010/464087.

4. Brooks GF, Butel JS, Morse SA. The neisserieae. 23rd ed. New York: Lange/Mc Graw-Hill; 2004.

5. Kluytmans J, van Belkum A, Verbrugh H. Nasal carriage of Staphylococcus aureus: Epidemiology, underlying mechanisms, and associated risks. Clin Microbiol Rev. 1997;10(3):505-20. [PubMed: 9227864]. [PubMed Central: PMC172932].

6. Defez C, Fabbro-Peray P, Bouziges N, Gouby A, Mahamat A, Daures $\mathrm{JP}$, et al. Risk factors for multidrug-resistant Pseudomonas aeruginosa nosocomial infection. J Hosp Infect. 2004;57(3):209-16. doi: 10.1016/j.jhin.2004.03.022. [PubMed: 15236849].

7. Harris AD, Smith D, Johnson JA, Bradham DD, Roghmann MC. Risk factors for imipenem-resistant Pseudomonas aeruginosa among hospitalized patients. Clin Infect Dis. 2002;34(3):340-5. doi: 10.1086/338237. [PubMed: 11774081].

8. Akahane K, Sakai D, Furuya N, Komano T. Analysis of the pilU gene for the prepilin peptidase involved in the biogenesis of type IV pili encoded by plasmid R64. Mol Genet Genomics. 2005;273(4):350-9. doi: 10.1007/s00438-005-1143-8. [PubMed: 15838638].
9. Chambers D, Scott F, Bangur R, Davies R, Lim A, Walters S, et al. Factors associated with infection by Pseudomonas aeruginosa in adult cystic fibrosis. Eur Respir J. 2005;26(4):651-6. doi 10.1183/09031936.05.00126704. [PubMed:16204596].

10. Hacker J, Carniel E. Ecological fitness, genomic islands and bacterial pathogenicity. A Darwinian view of the evolution of microbes. EMBO Rep. 2001;2(5):376-81. doi: 10.1093/embo-reports/kve097. [PubMed: 11375927]. [PubMed Central: PMC1083891].

11. Ryall B, Davies JC, Wilson R, Shoemark A, Williams HD. Pseudomonas aeruginosa, cyanide accumulation and lung function in $\mathrm{CF}$ and non-CF bronchiectasis patients. Eur Respir J. 2008;32(3):740-7. doi: 10.1183/09031936.00159607. [PubMed: 18480102].

12. Dobrindt U, Hochhut B, Hentschel U, Hacker J. Genomic islands in pathogenic and environmental microorganisms. Nat Rev Microbiol. 2004;2(5):414-24. doi:10.1038/nrmicro884. [PubMed:15100694].

13. Javad Zadeh M, Debir S, Zangi Abadi M. [The role of Shigella, Escherichia coli and Antibacterial colitis in children's bloody diarrhea and its microbial susceptibility]. Zahedan Univ Med Sci J. 1382;13(39):29-35. Persian.

14. Mozaffarian V. dictionary of plant names in Iran. 6th ed. Contemporary Culture Concepts; 2009.

15. Hosseini H, Rouhani MH, Sadeghi M, Saratov K. Research project on the study of the ecological characteristics of Zaman and its economic value in Bushehr province. Natural Resources and Animal Sciences Research Center of Bushehr Province; 2000. 75 p.

16. Singh G. Comparative productivity of Prosopis cineraria and Tecomella undulata based agroforestry systems in degraded lands of Indian Desert. J Forest Res. 2009;20(2):144-50. doi:10.1007/s11676-0090025-z.

17. Crisan M, Yap S, Casteilla L, Chen CW, Corselli M, Park TS et al. A perivascular origin for mesenchymal stem cells in multiple human organs. Cell Stem Cell. 2008;3(3):301-13. doi: 10.1016/j.stem.2008.07.003. [PubMed: 18786417].

18. Alizadeh Behbahani B, Shahidi F, Tabatabaei Yazdi F, Mohebbi M. Antifungal effect of aqueous and ethanolic mangrove plant extract on pathogenic fungus" in vitro". Int J Agron Plant Prod. 2013;4(7):1652-8.

19. Ghaderi AA, Fakheri B, Mahdinezhad N, Saeedi S. [Assessment of the antimicrobial effects of the Vulgaris thymus ethanol extract against human pathogenic bacteria]. J Sabzevar Univ Med Sci. 2016;23(5):75661. Persian. doi: 10.21859/sums-2305756.

20. Mehraban A, Haddadkhodaparast MH, Mehrabansangatash M. [Evaluation of inhibitory and lethal effects of aqueous ethanolic and hydroalcoholic extracts of aerial parts of salvia chorassanica against some gram negative and gram positive bacteria in vitro]. Qom Uni Med Sci J. 2016;10:2-11. Persian.

21. Sunenshine RH, Wright MO, Maragakis LL, Harris AD, Song X, Hebden J, et al. Multidrug-resistant Acinetobacter infection mortality rate and length of hospitalization. Emerg Infect Dis. 2007;13(1):97-103. doi: 10.3201/eid1301.060716. [PubMed: 17370521]. [PubMed Central: PMC2725827].

22. Mazel D, Davies J. Antibiotic resistance in microbes. Cell Mol Life Sci. 1999;56(9-10):742-54. doi: 10.1007/s000180050021. [PubMed: 11212334].

23. Toyang NJ, Verpoorte R. A review of the medicinal potentials of plants of the genus Vernonia (Asteraceae).JEthnopharmacol.2013;146(3):681723. doi: 10.1016/j.jep.2013.01.040. [PubMed: 23395623].

24. Ghaderi S, Falahati-HosseinAbad A, Sarailoo MH, Ghanbari V. [Investigation of the components and antibacterial effects of three plant's essential oil Coriandrum sativum, Achilleh millefolium, Anethum graveolens in vitro]. J Shahrekord Uuniv Med Sci. 2012;14(5):74-82. Persian.

25. Abhishek S, Ujwala P, Shivani K, Meeta B. Evaluation of antibacterial activity of Tecomella undulata leaves crude extracts. Int Res J Biological Sci. 2013;2(6):60-2. 
26. Bhardwaj R. GC-MS analysis and antimicrobial activity of alkaloids of Tecomella undulata.J Med Plants. 2018;6(6):68-72.

27. Thanawala PR, Jolly CI. Pharmacognostical, phytochemical and antimicrobial studies on stem bark of tecomella undulata seem. Ancient Sci Life. 1993;12(3-4):414.

28. Akinsiku AA, Ajanaku KO, Adebisi AA, Edobor-Osoh A, Aladesuyi O, Samson TO, et al. Momordica charantia stem extract mediated biogenic synthesis of silver nanoparticles: Optical and antimicrobial efficacy. IOP Conference Series: Mater Sci Eng. 2019;509:12018. doi: $10.1088 / 1757-899 \times / 509 / 1 / 012018$
29. Nguyen TTT, Vo DM, Luong THV, Phan HTT, Nguyen DP. Investigation of antimicrobial activity and chemical constituents of momordica charantia l. Var. Abbreviata ser. Vietnam J Sci Tech. 2019;57(2):155. doi: 10.15625/2525-2518/57/2/12727.

30. Subramaniam S, Keerthiraja M, Sivasubramanian A. Synergistic antibacterial action of $\beta$-sitosterol-d-glucopyranoside isolated from Desmostachya bipinnata leaves with antibiotics against common human pathogens. Revista Brasileira de Farmacognosia. 2014;24(1):44-50. doi: 10.1590/0102-695x20142413348. 